\title{
Improving the legal regulation of road safety
}

\author{
Kamoliddin RAKHIMOV 1 \\ University of Public Security of the Republic of Uzbekistan on Legal Issues
}

\begin{tabular}{l} 
ARTICLE INFO \\
\hline Article history: \\
Received July 2021 \\
Received in revised form \\
20 July 2021 \\
Accepted 15 August 2021 \\
Available online \\
15 September 2021 \\
\hline
\end{tabular}

\section{Keywords:}

road traffic,

road safety,

legal regulation,

offense,

law,

decision,

legislation,

internal departmental

documents,

regulation.

\begin{abstract}
The article analyzes the theoretical and practical aspects of the legal regulation of road safety. There are legislative acts of the Republic of Uzbekistan in the field of road safety, their impact on road safety, proposals for their improvement. The author of the article focuses on the features of the study of road safety legislation and indicates that they are aimed at regulating the organizational aspects of road safety and relationships after the offense. It is proposed to develop a government decree on the introduction of a formal warning procedure. drivers about serious administrative consequences that await them in the future.
\end{abstract}

2181-1415/C) 2021 in Science LLC.

This is an open access article under the Attribution 4.0 International (CC BY 4.0) license (https://creativecommons.org/licenses/by/4.0/deed.ru)

\section{Йўл харакати хавфсизлигини таъминлашни хуқуқий тартибга солишни такомиллаштириш}

\footnotetext{
Калит сўзлар:

йўл харакати,

йўл харакати хавфсизлиги, хукуқий тартибга солиш, хуқуқбузарлик, қонун, қарор, қонун хужжатлари, ички идоравий хужжатлар, тартибга солиш.
}

\begin{abstract}
АННОТАЦИЯ
Мақолада йўл харакати хавфсизлигини таъминлашни хуқуқий тартибга солишнинг назарий ва амалий жихатлари тахлил қилинган. Ўзбекистон Республикасининг йўл харакати хавфсизлигини таъминлаш сохасига диор айрим қонун хужжатлари, уларнинг харакат хавфсизлигини таъминлашга таъсири, уларни такомилллаштириш бўйича таклифлар келтирилган. Мақола муаллифи йўл харакати хавфсизлигига оид қонун хужжатларини ўрганиб чиқиш давомида уларнинг ўзига хос хусусиятига эътибор қаратади ва уларни йўл харакати хавфсизлигининг ташкилий жихатларини ва хуқуқбузарлик содир этилганидан кейинги
\end{abstract}

\footnotetext{
${ }^{1}$ Assistant to the Head of the University of Public Security of the Republic of Uzbekistan on Legal Issues, Tashkent, Uzbekistan.
} 
муносабатларни тартибга солишга қаратилганлигини кўрсатиб, сохага қоидабузар хайдовчилар билан якка тартибда профилактика олиб боришни, қўпол ва такрорий хукуқбузарлик содир этган хайдовчиларни келгусида уларни кутаётган жиддий маъмурий оқибатлар хақида расмий огохлантириш тартибини жорий этувчи Хукумат қарорини ишлаб чиқишни таклиф этади.

\section{Совершенствование правового регулирования обеспечения безопасности дорожного движения}

\author{
Ключевые слова: \\ дорожное движение, \\ безопасность дорожного \\ движения, \\ правовое регулирование, \\ правонарушение, \\ закон, \\ решение, \\ законодательство, \\ внутренние \\ ведомственные \\ документы, \\ регулирование.
}

\begin{abstract}
АННОТАЦИЯ
В статье анализируются теоретические и практические аспекты правового регулирования безопасности дорожного движения. Существуют законодательные акты Республики Узбекистан в области безопасности дорожного движения, их влияние на безопасность дорожного движения, предложения по их совершенствованию. Автор статьи акцентирует внимание на особенностях изучения законодательства о безопасности дорожного движения и указывает, что они направлены на регулирование организационных аспектов безопасности дорожного движения и взаимоотношений после правонарушения. Предлагается разработка постановления Правительства о введении формальной процедуры предупреждения водителям о серьезных административных последствиях, которые ждут их в будущем.
\end{abstract}

Human society is characterized by a certain degree of orderliness, a certain form of organization and association. Life is made up of a variety of social relationships, each of which feels the need for normative regulatory tools. Traffic is one of the main organizational elements of any society, social space. The need for regulatory regulation in this area stems from the diversity of needs and interests of social groups, ie road users, and the need to coordinate them. The movement of vehicles at any speed is dangerous, and an increase in speed is directly proportional to an increase in risk. Therefore, there is a need to ensure road safety for all road users.

The need for legal regulation is an objective necessity. After all, regular rhythm and orderliness are the order of any mode of production, which leads to social stability and independence. Strict discipline protects economic development from coincidences and chaos. Such a procedure can only be ensured by a law based on the coercive power of the state. Legal norms reflect the model of activity of participants of social relations, behavior of people, algorithms of behavior, norms of the rights and obligations of the parties. Law regulates social relations by regulating human behavior in the form of subjective rights and legal obligations [1].

Here it is necessary to analyze the meaning of the phrase "legal regulation". Legal regulation is the process of influencing social relations through law in order to regulate them in a mandatory, normative way. An important feature of legal regulation is that it defines the legal rights and obligations of the participants of social relations, ensures the exercise of rights and the fulfillment of obligations [2]. 
The increase in the number of vehicles, the intensity of traffic on the roads leads to an increase in traffic accidents on highways. In the first 4 months of 2021, in January-April, a total of 242 traffic accidents occurred in the country, resulting in 557 deaths and 1684 injuries. 983 pedestrians, 146 cyclists, 243 children and 12 motorcyclists were involved in traffic accidents. Among the factors that led to the accident were speeding - 32.4\%, crossing an unspecified place due to lack of pedestrian crossings $-16.2 \%$, not to miss a privileged vehicle $11.6 \%$, going in the opposite direction $-9,3$ percent. In addition, the inexperience of drivers is the cause of all traffic accidents while falling asleep at the wheel caused 5.9 percent, driving while intoxicated caused 3.1 percent of crashes. Other cases accounted for 7.9 percent [3].

Today, in order to avoid traffic accidents, road users must be vigilant and focused while driving on highways, and unconditionally obey and follow the rules of the road. The reasons for the increase in the number of vehicles, the intensity of traffic on the road, the unsatisfactory supply of demand for public transport, problems in the field of logistics, the inadequacy of the highway cannot be quickly eliminated. However, the current situation can be changed for the better with the help of a legal tool aimed at ensuring the compliance of road users with traffic rules by the state. Recognizing this fact, most countries are working to strengthen the measures taken against violators of traffic rules, to ensure the inevitability of punishment, and this is a mandatory measure, which serves to "quickly" reduce the number of accidents on highways.

Analysis of the available data and the above statistics show the need to further improve the legal regulation of road safety.

Based on the above definition, the legal regulation of road safety can be defined as follows: the process of influencing the relationship between all participants in the field of road safety in order to regulate them in a mandatory, normative manner by law. While the legal regulation of road safety regulates the vital relations of traffic safety, it establishes a certain limit, a clear norm for their implementation and development. In this way it regulates them in terms of the interests of society and the state.

The Republic of Uzbekistan has adopted more than 50 pieces of legislation governing road safety. These include the Law of the Republic of Uzbekistan "On Road Safety"; Resolution of the President of the Republic of Uzbekistan "On measures to further improve the system of road safety" dated July 11, 2017 No PP-3127; More than 30 decisions of the Cabinet of Ministers in this area, more than 10 internal departmental documents of the Ministry of Internal Affairs can be included.

The main goal of legal regulation is the formation of motivating motives that encourage active behavior that lead to positive behavior. The formation of motivating motives is done in two ways:

- the first is the imposition of an obligation to take active action;

- the second is to give (authorize) the right to commit a positive action [4].

In accordance with these rules, in order to increase the role of the public in improving the effectiveness of combating traffic offenses, the Cabinet of Ministers adopted a resolution dated September 20, 2018 No. 747 "On additional measures to increase the effectiveness of combating traffic offenses". A procedure has been introduced to encourage individuals who report traffic offenders. Paragraph 5 of paragraph 4 of this decision stipulates that those who send videos of violations will be rewarded with a monetary reward in the amount of five percent of the base amount of the fine imposed on the offender [5].

In accordance with the resolution, the "Regulations on the procedure for receiving, reviewing and rewarding video submissions of individuals and legal entities on video recorders installed in vehicles, as well as video surveillance and video equipment and mobile devices" were 
approved. The website ejarima.uz has been launched on the World Wide Web, developed by the State Road Safety Department of the Ministry of Internal Affairs.

According to the data, to date, the website ejarima.uz has 19,473 users and the number of violations is 243,385 [6].

In addition, the Cabinet of Ministers adopted a resolution No. 377 of 19 May 2018 "On measures to further improve the road safety system of the Republic of Uzbekistan", according to which every week on Friday "Road Safety Day" is held, in which all ministries and departments as well as other organizations take active measures to ensure unconditional compliance with traffic rules and prevention of road accidents; The monthly campaign "Car-free day" is organized on a regular basis in all regions of the country, aimed at drawing public attention to the problem of road safety, demonstrating the possibility and necessity of driving without vehicles, a public call to all its participants to follow traffic rules [7].

In our view, while the above-mentioned decisions oblige individuals to take active action and give them the right to take positive action, these rules do not achieve the goals of improving road safety in Uzbek society. Proof of this can be found in the statistics on traffic accidents shown above. In this regard, it is advisable to use other effective methods of legal regulation in the field of road safety, to improve them.

The method of legal regulation is to influence the behavior and will of the participants in the legal relationship[8].

Traffic participants need to understand that their behavior while driving on highways depends on a deep sense of responsibility, especially when the driver of a motor vehicle feels that the life and health of not only himself but also other road users is directly related to his behavior. In our view, given that in this case the driver is more concerned with his own material and financial condition than with his own life and the health of others, it becomes clear that the object of influence on his behavior and will is his material and financial condition. It should be borne in mind that the desired effect can be achieved only if the driver's offense is a serious threat to society and the state, the vital interests of the individual, a serious increase in fines, coercive measures, as well as legal, social and psychological mechanisms of road safety.

The legal mechanism of legal regulation in ensuring road safety includes the adoption and implementation of the Constitution, laws of the Republic of Uzbekistan, decrees and resolutions of the President of the Republic of Uzbekistan, Government decisions and internal departmental documents of relevant ministries and departments. Circumstances such as some shortcomings in the legislation or their inability to adequately affect the realities of life lead to the inability to prevent, prophylaxis, and, for some, to have a serious impact.

Chapter XI of the Code of Administrative Responsibility, established by the Law of the Republic of Uzbekistan No. 289 of April 26 in 2011, is supplemented with 5 new articles (1251, 1283-1286), amendments and additions to 12 articles [9]. Some gross violations were singled out as a separate article and their sanctions were strengthened. Although the law increases penalties for speeding, the analysis of data shows that these norms do not have the power to influence the offense.

In particular, almost all of the road accidents that occurred during 2020Forty-five percent were caused by motorists failing to comply with established speed limits [10].

For exceeding the speed limit set by drivers of vehicles under Article 128-3 of the administrative Code there are 5 levels of responsibility. Of these, the responsibilities in paragraphs 4 and 5 define an enhanced form of liability for drivers of vehicles to repeat the offense within one year after the imposition of an administrative penalty for the offense [11]. 
In case of violation of traffic rules by means of special automated photo and video recording equipment, Article 17-1 of the Administrative Code does not take into account the recurrence of the offense, except as provided in the third part of Article 321 of the Administrative Code. This rule causes the practical failure of paragraphs 4 and 5 of Article 128-3 of the Administrative Code [12]. In fact, the application of a more severe type of punishment for recidivism ensures the prevention of offenses. At present, the detection of speeding and speeding of motor vehicle drivers is detected only by special automated photo and video recording equipment, and no other method is used.

There are two methods of legal regulation of road safety in the world community:

1. Direct administrative penalty for the offense (fine, deprivation of a certain person of the special right granted to him (the right to drive a vehicle, the right to hunt); administrative detention;

2. Scoring system. Along with the administrative penalty for the offense, points are also calculated.

The second method uses a "traditional" administrative penalty for the offense, as well as a scoring system. The essence of this system is that for each offense a point is awarded or a certain point is deducted, the collected points exceed the norm established by the legislation or the offending drivers are punished by deprivation of the right to drive [13].

In our opinion, the best foreign experience (PRC, Georgia, Given the GFR, the UK, France, Austria and other countries), it is time to introduce a modern scoring system that holds drivers accountable and encourages them. At the same time, points are awarded for each violation of traffic rules by means of special automated photo and video recording equipment [14]. Serious sanctions are applied to drivers whose points accumulated during the year exceed the norm specified in the legislation. This, in turn, serves to prevent recidivism by drivers.

Nine percent of traffic accidents during 2020 were caused by motorists exiting on the opposite side of the road or on a section intended for oncoming traffic and not following the rules of overtaking. During the reporting period, 38,063 overtaking violations were detected [15].

Article 128 of the Code of Criminal Procedure of the Republic of Uzbekistan stipulates liability for violation of the rules of chasing vehicles, according to which drivers who violate this requirement will be fined in the amount of one-half of the basic amount. If the same offense is repeated within one year after the imposition of an administrative penalty - a fine equal to the amount of the basic calculation. Recidivism of the same offense within one year after the imposition of two administrative penalties - entails a fine in the amount of three times the amount of the basic calculation. recidivism of the same offense three times or more within one year after the imposition of an administrative penalty - entails a fine of four times the basic amount or deprivation of the right to drive a vehicle for a period of six months [16].

According to the rules of the road, overtaking is a departure from the occupied part of the traffic and overtaking the vehicle moving ahead [17]. On two-lane roads with two-way traffic, overtaking is carried out in accordance with safety rules, by exiting the lane in the opposite direction. According to the above information, it is observed that safety requirements are not observed by drivers crossing in the opposite direction during the chase. In our view, drivers are being negligent in relation to this offense because the administrative penalty for violating the chasing rules is light. In addition, this violation is detected through visual observation by Government Road Safety Services staff or photo and video materials sent by active citizens of the community to the special electronic platform of Government Road Safety Servis. These factors are also a factor that allows drivers to commit these types of violations. 
In our opinion, given that the opposite direction occurs during the direct pursuit, these two offenses are given in two separate articles of the Administrative Code, and the lightness of the penalty for the pursuit leading to the opposite direction, as well as the seriousness of this type of offense. This requires that these violations be reflected in a single, separate article and that penalties be strengthened for them.

In order to strengthen the responsibility for overtaking and going to the opposite lane, it is necessary to add a new article to the Administrative Code for this violation in the following edition:

"Article 128-7. Violation of the rules of overtaking by drivers of vehicles on the side or part of the road intended for oncoming traffic

Drivers of vehicles going to the side or part of the road intended for oncoming traffic, violating the rules of overtaking, -

will result in a fine of ten times the base calculation amount.

Repetition of these offenses within one year after the imposition of an administrative penalty, - a fine of fifteen times the basic calculation amount or deprivation of the right to drive a vehicle for a period of one year".

In our view, Article 266 of the Criminal Code is entitled "Violation of the rules of traffic or safety of use of vehicles" and the concepts in the disposition of this title and article do not correspond to the essence used in practice [18].

The Laws of the Republic of Uzbekistan "On Road Safety", "On Motor Roads", "On Compulsory Civil Liability Insurance of Vehicle Owners", "On Motor Transport" and other legislation do not use and do not use the concept of "traffic rules". In addition, the "Rules of the Road" approved by the Cabinet of Ministers on December 24, 2015 No. 370 does not contain the concept of "rules of the road" [19]. It is also important that the rules of the road are not reflected in any normative legal document, and in practice these words are applied in a sense close to the rules of the road.

It should be noted that the use of the term "vehicle" is controversial. Because there are many types and forms of vehicles. For example, rail, air, water transport, etc. In addition to the concept of "vehicle" in the legislation, such concepts as "car", "motor vehicle" and "automotor vehicle" were used. In particular, the Code of Administrative Responsibility of the Republic of Uzbekistan, the Law "On Road Safety", the Law "On Motor Roads", decrees, resolutions of the President of the Republic of Uzbekistan and the Cabinet of Ministers, internal departmental documents of ministries and departments.

The social relations provided for in Article 266 of the CC apply to motor vehicles, while other articles of the Code specify other modes of transport by their names (for example, Article 260 of the CC defines "violation of traffic, sea, river or air traffic safety rules". In which the types of vehicles are listed separately).

In accordance with the requirements of Article 24 of the Law of the Republic of Uzbekistan "On regulatory legal acts", the text of the regulatory legal act is stated in a concise, simple and fluent language. Concepts used in the normative legal document and the terms are used in a single form in accordance with their accepted meaning in the legislation, which excludes the possibility of different interpretations. The use of obsolete and ambiguous words and phrases, figurative comparisons, adjectives, allusions is not allowed[20].

Based on the above, the title and disposition of Articles 266, 267 of the Criminal Code should be stated as follows:

"Article 266. Violation of traffic rules or safety rules for the use of motor vehicles 
If the violation of traffic rules or safety rules of use of motor vehicles by the person driving the motor vehicle causes moderate or severe damage to health, -

"Article 267. Vehicle hijacking

Vehicle hijacking -"

During the study of normative legal acts regulating road safety, it can be observed that they are mainly focused on organizational issues, the regulation of relations arising after the offense. The penalties set out in the Administrative Code are also certainly applicable to offenders and can only have a prophylactic effect on those who are aware of them, if their legal consciousness and culture are sufficiently formed. The current state of road safety indicates the need for additional preventive measures, in addition to administrative penalties for drivers who regularly violate traffic rules or grossly violate traffic rules.

Resolution of the Cabinet of Ministers of the Republic of Uzbekistan "On approval of the form of official warning issued by officials of bodies or institutions directly involved in crime prevention and the Regulation on the procedure for its issuance" dated February 7, 2017 [21] Regulations on the procedure of Paragraph 6 of this Regulation provides that a formal warning shall consist of a written explanation to the person that he may not be allowed to continue his antisocial behavior, as well as a warning to the person prone to committing the offense of liability for the offense.

In our opinion, it is expedient to develop a decision of the Cabinet of Ministers on the application of the preventive measure "official warning" provided for in the above Government decision for drivers who grossly violate traffic rules or regularly commit violations. The proposed resolution provides for individual preventive interviews with offending drivers, warning them about the impending serious administrative measures. An electronic database of drivers who have received an official warning will be formed and interviewed by Government Road Safety service staff on a quarterly basis, and discussions will be held with the participation of the community and the public if no changes are observed. These measures increase the responsibility of drivers for traffic rules, causing them to feel that they are under special control by the state, not to be overlooked, and to have a psychological impact.

\section{REFERENCES:}

1. Theory of state and law. A. Azamkhodjaev and Sh. Edited by Orazavv. T., 1992. P. 255.

2. The theory of state and law. A. Azamkhodjaev and Sh. Edited by Orazavv. T., 1992.P. 255.

3. URL: https: //dyhxx.uz/.

4. Theory of state and law. A. Azamkhodjaev and Sh. Edited by Orazavv. T., 1992. P. 255.

5. Resolution of the Cabinet of Ministers No. 747 "On additional measures to increase the effectiveness of the fight against traffic offenses". 20.09.2018 // URL: https: //lex.uz/docs/4089918.

6. URL: https: //dyhxx.ejarima.uz/login.

7. Resolution of the Cabinet of Ministers of the Republic of Uzbekistan "On approval of the Regulation on the interaction of road patrol officers with road users and the use of special equipment". No. 975. 01.12.2018 // URL: https: //lex.uz/docs/4089917.

8. Theory of state and law. A.Azamkhodjaev and Sh. Edited by Orazavv. T., 1992. P. 255. 
9. Law of the Republic of Uzbekistan "On amendments and additions to the Code of the Republic of Uzbekistan on Administrative Liability". No. ORQ-289. 26.04.2011 // URL: https: //lex.uz/docs/1779341.

10. URL: https: //dyhxx.uz/.

11. Law of the Republic of Uzbekistan "On Amendments and Addenda to the Code of the Republic of Uzbekistan on Administrative Responsibility". No. ORQ-289. 26.04.2011 // URL: https: //lex.uz/docs/1779341.

12. Law of the Republic of Uzbekistan "On Amendments and Addenda to the Code of the Republic of Uzbekistan on Administrative Responsibility". No. ORQ-289. 26.04.2011 // URL: https: //lex.uz/docs/1779341.

13. Golovko V.V., Beketov O.I., Mayorov V.I. Lishenie prava upravleniya transportnym sredstvom v sisteme administrativnyx nakazaniy: sovremennыe tendentsii i perspektivy // Administrativnoe pravo i protsess. 2017. № 7. - S. 25-29.

14. Resolution of the Cabinet of Ministers No. 377 "On measures to further improve the system of road safety in the Republic of Uzbekistan". 19.05.2018y. URL: https: //lex.uz/docs/3743453.

15. URL: https: //dyhxx.uz/.

16. Code of the Republic of Uzbekistan on Administrative Responsibility 22.09.1994 // URL: https: //lex.uz/docs/97664.

17. Resolution of the Cabinet of Ministers of the Republic of Uzbekistan "On approval of traffic rules" dated 24.12.2015. Resolution No. 370. https: //lex.uz/docs/2850459.

18. Criminal Code of the Republic of Uzbekistan 22.09.1994 // URL: https://lex.uz/docs/97665

19. Resolution of the Cabinet of Ministers No. 370 "On approval of traffic rules", 24.12.2015. https://lex.uz/docs/2850459.

20. Law of the Republic of Uzbekistan "On regulatory legal acts". Lex.uz.

21. Resolution of the Cabinet of Ministers of the Republic of Uzbekistan "On approval of the form of official warning issued by officials of bodies or institutions directly involved in crime prevention and the Regulation on the procedure for its issuance" dated 07.02.2017. The decision. Lex.uz. 